\title{
Particulate Matter from Non-exhaust Sources
}

\author{
Filippo G. Praticò (D), Paolo G. Briante \\ Department of Information Engineering, Infrastructure and Sustainable Energy (DIIES), \\ Mediterranea University, Reggio Calabria, Italy
}

Received 04 February 2020; accepted 24 March 2020

\begin{abstract}
Air pollution is an important issue worldwide. Solid components in air (particulate matter, PM) originate from a variety of natural or anthropogenic sources and have different morphological, physical, and chemical properties. Their presence in the air also depends on meteorological conditions, such as humidity, rainfall, and wind speed. PM pollution has adverse effects on environment and human health. Therefore, it is very important to address sources and processes involved in PM generation. Among the existing sources, a special attention must be paid to PM emissions from road traffic, i.e., exhaust sources (e.g., fuel combustion) and non-exhaust sources (e.g., road, tyre, brakes). These traffic-related sources contribute to PM concentrations in cities, and this calls for research into new possible systems and/or mitigation measures. In light of the facts above, the objectives of this study are 1) To evaluate the contribution to PM emission from traffic-related sources. 2) To evaluate existing mitigation measures and to identify new ones to reduce PM production. First results show that: 1) Non-exhaust sources have a different role in PM generation and they differently affect $\mathrm{PM}_{10}, \mathrm{PM}_{2.5}$, and $\mathrm{PM}_{0.1}$. 2) Even if emissions-related regulations have led to reductions in exhaust emissions from road traffic, other mitigation measures could reduce the non-exhaust part of emissions (e.g., brakes wear, road wear, and tyre wear). 3) New technologies could be developed to reduce PM from non-exhaust sources.
\end{abstract}

Keywords: particulate matter, non-exhaust sources, tyre wear, road wear, brake wear, mitigation measures.

\section{Introduction}

Based on pollution source, particulate matter (PM) is made up of very heterogeneous compounds in terms of chemical composition, solid or liquid state, and size. PM classification is usually based on the aerodynamic diameter (the one that appears as a subscript). This latter is the diameter of a spherical particle with a density of $1 \mathrm{~g} / \mathrm{cm}^{3}$ with the same settling velocity: 1) Total Suspended Particles (TSP) including all particles, of whatever size lower than $35 \mu \mathrm{m}$ (Heinrich \& Slama, 2007); 2) $\mathrm{PM}_{10}$ (less than $\left.10 \mu \mathrm{m}\right)$. 3) $\mathrm{PM}_{2.5}\left(<2.5 \mu \mathrm{m}\right.$ in diameter). 4) $\mathrm{PM}_{1.0}(<1 \mu \mathrm{m}$ in diameter). 5) Coarse particles (particles which are from 2.5 to 10). 6) Fine particles (particles less than 2.5 in diameter), that include $\left.\mathrm{PM}_{0.1} .7\right)$ Ultra-fine particles $\left(<0.1 \mu \mathrm{m}\right.$, i.e., $\left.\mathrm{PM}_{0.1}\right)$. Furthermore, $\mathrm{PM}$ can be classified as primary or secondary particles: 1) Primary particles (i.e., fine, $\mathrm{PM}_{2.5}$ and ultrafine particles, $\mathrm{PM}_{0.1}$ ) are directly released into the atmosphere by a large number of human or natural sources (e.g., combustion processes) (Reddington et al., 2011). 2) Secondary particles (including coarse particles with diameters greater than $2.5 \mu \mathrm{m}, \mathrm{PM}_{10}$ and TSP) are generated by mechanical or chemical reactions during the atmospheric oxidation of emitted precursor gases (e.g., sulfur dioxide, nitrogen oxides, ammonia, and volatile organic compounds). In this process, the saturation vapor pressure of the organic and inorganic gases becomes lower thus allowing them to transfer into particle phase by condensation and nucleation (Alanen et al., 2017; Reddington et al., 2011). Table 1 below shows a schematic PM classification.

Table 1. Particulate Matter Classification

\begin{tabular}{|c|c|c|c|c|}
\hline Category & PM Fraction & Particle Size & Acronym & Source \\
\hline \multirow{2}{*}{$\begin{array}{l}\text { Primary } \\
\text { particles }\end{array}$} & Ultra-fine & $<0.1 \mu \mathrm{m}$ & $\mathrm{PM}_{0.1}$ & \multirow{2}{*}{$\begin{array}{l}\text { Volcanoes, forest fires, sea spray, and windborne dust, } \\
\text { and anthropogenic sources (vehicles, engines or power } \\
\text { plants, and biogenic sources) (Reddington et al., 2011) }\end{array}$} \\
\hline & Fine & $<2.5 \mu \mathrm{m}$ & $\mathrm{PM}_{2.5}$ & \\
\hline \multirow{3}{*}{$\begin{array}{l}\text { Secondary } \\
\text { particles }\end{array}$} & \multirow[b]{2}{*}{ Coarse } & $<10 \mu \mathrm{m}$ & $\mathrm{PM}_{10}$ & \multirow{3}{*}{$\begin{array}{l}\text { Homogeneous nucleation (gas-to-particle conversion) } \\
\text { and condensation of both natural and anthropogenic } \\
\text { gaseous precursors. Also traffic and other anthropogenic } \\
\text { sources are contributors to secondary aerosol formation. } \\
\text { (Alanen et al., 2017; Reddington et al., 2011) }\end{array}$} \\
\hline & & $>2.5 \mu \mathrm{m} \&<10 \mu \mathrm{m}$ & $\mathrm{PM}_{2.5-10}$ & \\
\hline & Total suspended & $<35 \mu \mathrm{m}$ & TSP & \\
\hline
\end{tabular}

${ }^{*}$ Corresponding author. E-mail: paolo.briante@ gmail.com

\section{Copyright (C) 2020 The Author(s). Published by VGTU Press}

This is an Open Access article distributed under the terms of the Creative Commons Attribution License (http://creativecommons.org/licenses/by/4.0/), which permits unrestricted use, distribution, and reproduction in any medium, provided the original author and source are credited. 
Note that anthropogenic activities have a negative impact on PM pollution. Importantly, in addition to industrial processes, farming, building operations, combustion of fossil fuels, also road traffic significantly contributes. Based on the above, the objectives of the study presented in this paper are to 1) Analyze the emissions of particulate matter (i.e. $\mathrm{PM}_{10}, \mathrm{PM}_{2.5}$, and $\mathrm{PM}_{0.1}$ ) from traffic-related sources. 2) Evaluate existing mitigation measures and their effectiveness. 3) Provide a basis for a better understanding of traffic-related emissions in order to guide future research into new effective technologies and measures. The remaining part of this paper is organised as follows. Next section deals with the analysis of traffic-related PMs. Afterwards mitigations measures are discussed. Finally, Conclusions are drawn and references are listed.

\section{Analysis of traffic-related PMs}

In terms of PM thresholds and limits, note that the EU Directive 2008/50/EC (European Parliament, 2008), as well as the guidelines of the World Health Organization (WHO, 2006) set PM concentration thresholds (cf. Table 2). According to the EU Directive 2008/50/EC, the 24-hour average $\mathrm{PM}_{10}$ should not exceed $35 \mu \mathrm{g} / \mathrm{m}^{3}$ more than 35 times in a calendar year. WHO guideline values are generally stricter than the EU standards. In the U.S.A., the National Ambient Air Quality Standards (NAAQS) (Buchoolz, 2014) serves as a national public health and environment protection program. NAAQS refers to several contaminants (e.g., carbon monoxide $\mathrm{CO}$, nitrogen oxides $\mathrm{NO}_{2}$, ozone $\mathrm{O}_{3}$, sulfur dioxide $\mathrm{SO}_{2}$ and lead $\mathrm{Pb}$ ). For $\mathrm{PM}_{2.5}$, NAAQS provides a "primary standard" (for the protection of public health) and a "secondary standard" (for the protection of public welfare). $\mathrm{PM}_{2.5}$ limits are 12 and $15 \mu \mathrm{g} / \mathrm{m}^{3}$, respectively.

Table 2. Different sources contribution to $\mathrm{PM}_{2.5}$ and $\mathrm{PM}_{10}$

\begin{tabular}{|c|c|c|c|c|c|}
\hline \multirow{3}{*}{ Country } & \multicolumn{4}{|c|}{ Target Limit } & \multirow{3}{*}{ Reference } \\
\hline & \multicolumn{2}{|c|}{$\mathrm{PM}_{10}\left(\mu \mathrm{g} / \mathrm{m}^{3}\right)$} & \multicolumn{2}{|c|}{$\mathrm{PM}_{2.5}\left(\mu \mathrm{g} / \mathrm{m}^{3}\right)$} & \\
\hline & $24-\mathrm{H}$ & ANNUAL & 24-H & ANNUAL & \\
\hline EU & 50 & 40 & l & 25 & Directive 2008/50/EC \\
\hline EU & 50 & 20 & 25 & 10 & WHO Air-Quality Guidelines \\
\hline Norway & 30 & 20 & 15 & 8 & National Air-Quality Guidelines \\
\hline USA & 150 & I & 35 & $12-15$ & NAAQS \\
\hline Canada & & & 30 & & Canadian Council of ministries of Environment \\
\hline Australia & 50 & & 25 & 8 & Australia Government \\
\hline Japan & 100 & & 35 & 15 & Government of Japan \\
\hline
\end{tabular}

Traffic-related PMs can be distinguished into 1) Exhaust traffic-related particles, ES, which are emitted as a result of incomplete fuel combustion and lubricant volatilization during the combustion procedure. 2) Non-exhaust trafficrelated particles, NES, which are either generated from non-exhaust traffic related sources such as brake, tyre, clutch and road surface wear or already exist in the environment as deposited material and become resuspended due to traffic induced turbulence (Grigoratos \& Martini, 2014).

Based on the studies conducted in 51 countries around the world, Karagulian et al. (2015) assessed how the different sources identified contribute to air pollution (cf. Table 3). Note that, in decreasing order: 1) Unspecific anthropogenic sources are approximately 28-36\%. 2) The contribution of natural dust and sea salt is about $23-26 \%$. 3) Traffic (from exhaust, ES, and non-exhaust sources, NES) is a major contributor (about 23-25\%). 4) Domestic fuel burning (e.g., wood, coal and gas fuel for cooking / heating) accounts for about 20-24\%. 5) The share from industrial activities is about $17-19 \%$. For traffic, note that in several contexts it may result as the main source of PM (Karagulian et al., 2015). This is particularly evident in urban areas where vehicle emissions (e.g. carbon dioxide $\left(\mathrm{CO}_{2}\right)$, hydrocarbons (HCs), nitrogen oxides (NOx) and PM) are constantly increasing.

Table 3. Different sources contribution to $\mathrm{PM}_{2.5}$ and $\mathrm{PM}_{10}$

\begin{tabular}{|c|c|c|c|c|c|c|c|c|}
\hline \multirow{3}{*}{ Sources } & \multicolumn{4}{|c|}{ Traffic } & \multirow{3}{*}{ Industry } & \multirow{3}{*}{$\begin{array}{c}\text { Domestic Fuel } \\
\text { Burning }\end{array}$} & \multirow{3}{*}{$\begin{array}{l}\text { Natural } \\
\text { Sources }\end{array}$} & \multirow{3}{*}{$\begin{array}{l}\text { Unspecified Source } \\
\text { (of Human Origin) }\end{array}$} \\
\hline & \multirow{2}{*}{ ES } & \multicolumn{3}{|c|}{ NES } & & & & \\
\hline & & RW & BW & TW & & & & \\
\hline $\mathrm{PM}_{10}(\%)$ & \multicolumn{4}{|c|}{$8-38$} & $6-29$ & $3-45$ & $3-44$ & $12-44$ \\
\hline $\mathrm{PM}_{2.5}(\%)$ & \multicolumn{4}{|c|}{$12-37$} & $4-34$ & $6-34$ & $5-52$ & 9-62 \\
\hline
\end{tabular}

Note ES = Exhaust Sources; NES = Non Exhaust Sources; RW = Road Wear; BW = Brake Wear; TW = Tyre Wear. 
Based on literature results (Amato et al., 2014a; Denby et al., 2013; Hedberg et al., 2006; Kim \& Lee, 2018; Kwak et al., 2013; Panko et al., 2019, 2013; Schauer et al., 2002; Sjödin et al., 2010; Srimuruganandam \& Shiva Nagendra, 2012a, 2012b; Wåhlin et al., 2006; Weinbruch et al., 2014). Table 4 reports Contributions to Particulate Matter $\left(\mathrm{PM}_{10}\right.$ and $\left.\mathrm{PM}_{2.5}\right)$ from exhaust and non-exhaust sources.

Table 4. Results for Exhaust and Non-Exhaust (traffic related) Contributions to Particulate Matter ( $\mathrm{PM}_{10}$ and $\left.\mathrm{PM}_{2.5}\right)$

\begin{tabular}{|c|c|c|c|c|c|}
\hline \multirow{2}{*}{$\begin{array}{c}\text { Source } \\
\text { Category }\end{array}$} & \multirow{2}{*}{ Source } & \multicolumn{2}{|c|}{ PM concentration } & \multirow{2}{*}{$\begin{array}{c}\text { PM } \\
\text { size range }\end{array}$} & \multirow{2}{*}{ Reference } \\
\hline & & $\left(\mu \mathrm{g} / \mathrm{m}^{3}\right)$ & $\%$ & & \\
\hline \multirow{7}{*}{ ES/NES } & ES & $2.4-4.4$ & $10.3-19.2$ & \multirow{3}{*}{$\mathrm{PM}_{2.5}$} & \multirow{7}{*}{ (Sjödin et al., 2010) } \\
\hline & RW & $11.1-13$ & $48.8-57$ & & \\
\hline & BW & 5.8 & 25.5 & & \\
\hline & ES & $3.8-25.1$ & $13.1-43.6$ & \multirow{4}{*}{$\mathrm{PM}_{10}$} & \\
\hline & RW & $4-42.8$ & $7-80.4$ & & \\
\hline & BW & $0.02-42$ & $0.1-7.2$ & & \\
\hline & TW & $0.02-5.6$ & $0.06-10.2$ & & \\
\hline \multirow{6}{*}{ ES/NES } & ES & 4.3 & 55 & \multirow{3}{*}{$\mathrm{PM}_{2.5}$} & \multirow{6}{*}{ (Wåhlin et al., 2006) } \\
\hline & RW & 2.2 & 28.4 & & \\
\hline & BW & 0.72 & 9.3 & & \\
\hline & ES & 1.6 & 13.35 & \multirow{3}{*}{$\mathrm{PM}_{10}$} & \\
\hline & RW & 5.8 & 48.3 & & \\
\hline & $\mathrm{BW}$ & 0.1 & 0.8 & & \\
\hline \multirow{4}{*}{ ES/NES } & ES & $2.4-3.3$ & $10-20.1$ & \multirow[t]{4}{*}{$\mathrm{PM}_{10}$} & \multirow{4}{*}{ (Denby et al., 2013) } \\
\hline & RW & $7.8-23.8$ & $56.2-78$ & & \\
\hline & BW & $0.9-1.7$ & $5.5-5.9$ & & \\
\hline & TW & $0.8-1.9$ & $5.5-9.3$ & & \\
\hline \multirow{2}{*}{ ES/NES } & ES & 2.76 & 27 & \multirow{2}{*}{$\mathrm{PM}_{10}$} & \multirow{2}{*}{ (Weinbruch et al., 2014) } \\
\hline & $\mathrm{BW}+\mathrm{TW}$ & 1.6 & 15 & & \\
\hline \multirow{4}{*}{ ES/NES } & ES & 3.8 & 6 & \multirow{2}{*}{$\mathrm{PM}_{2.5}$} & \multirow{4}{*}{ (Srimuruganandam \& Shiva Nagendra, 2012a) } \\
\hline & $\mathrm{BW}+\mathrm{TW}$ & 3.4 & 5.4 & & \\
\hline & ES & 13.1 & 15.8 & \multirow{2}{*}{$\mathrm{PM}_{10}$} & \\
\hline & $\mathrm{BW}+\mathrm{TW}$ & 3.4 & 4.1 & & \\
\hline \multirow{4}{*}{ ES/NES } & ES & 23.5 & 57.7 & \multirow{2}{*}{$\mathrm{PM}_{2.5}$} & \\
\hline & BW & 0.09 & 0.14 & & \\
\hline & ES & 31.9 & 58.5 & & (Srimuruganandam \& Shiva Nagendra, 2012b) \\
\hline & $\mathrm{BW}$ & 3.4 & 8 & $\mathrm{PM}_{10}$ & \\
\hline & ES & 6.5 & 18 & & \\
\hline & TW & 6.6 & 18 & $\mathrm{PM}_{2.5}$ & \\
\hline ES/NES & ES & 8.8 & 20 & & (Amato et al., 2014a) \\
\hline & TW & 3.4 & 8 & $\mathrm{PM}_{10}$ & \\
\hline NES & BW & 0.6 & 14 & $\mathrm{PM}_{2.5}$ & (Hedberg et al., 2006) \\
\hline & ES & $11.9-25.9$ & $30.1-37.4$ & $\mathrm{PM}_{2.5}$ & \\
\hline ES/NES & TW & $0.4-2$ & $1-3.3$ & & (schauer et al., 2002) \\
\hline & $\mathrm{TW}+\mathrm{RW}$ & $0.004-0.29$ & $0.1-0.68$ & $\mathrm{PM}_{2.5}$ & \\
\hline NES & $\mathrm{TW}+\mathrm{RW}$ & $0.05-1.34$ & $0.14-2.8$ & $\mathrm{PM}_{10}$ & (Panko et al., 2019, 2013) \\
\hline & TW & $13.8-28.7$ & $4-7$ & $\mathrm{PM}_{2.5}$ & \\
\hline NES & TW & $20.8-37.1$ & $3-4$ & $\mathrm{PM}_{10}$ & (Kwak et al., 2013) \\
\hline NES & TW & $2-7$ & $0.04-0.12$ & $\mathrm{PM}_{2.5}$ & $(\mathrm{Kim} \& \mathrm{~J}$ e 2018$)$ \\
\hline NES & TW & $13-22.2$ & $0.12-0.40$ & $\mathrm{PM}_{10}$ & $(\mathrm{~N} M \mathrm{~m} \alpha \mathrm{Lee}, 2010)$ \\
\hline
\end{tabular}

Note : ES = Exhaust Source; NES = Non Exhaust Source; RW = Road Wear; BW = Brake Wear; TW = Tire Wear. 
On average, for exhaust sources (ES), $\mathrm{PM}_{10}$ accounts for about $10 \mu \mathrm{g} / \mathrm{m}^{3}$, while for non-exhaust sources (NES), $\mathrm{PM}_{10}$ accounts for about $12 \mu \mathrm{g} / \mathrm{m}^{3}$. Furthermore, on average, for ES, $\mathrm{PM}_{2.5}$ accounts for about $11 \mu \mathrm{g} / \mathrm{m}^{3}$, while, for NES, $\mathrm{PM}_{2.5}$ accounts for about $19 \mu \mathrm{g} / \mathrm{m}^{3}$. Note that, in Table 4 , when $\mathrm{PM}_{2.5}>\mathrm{PM}_{10}$ data are not consistent and refer to different authors/studies. Figure 1 shows 1) How $\mathrm{PM}_{2.5}$ and $\mathrm{PM}_{10}$ relate. 2) Typical relationships among NES components (Sjödin et al., 2010).
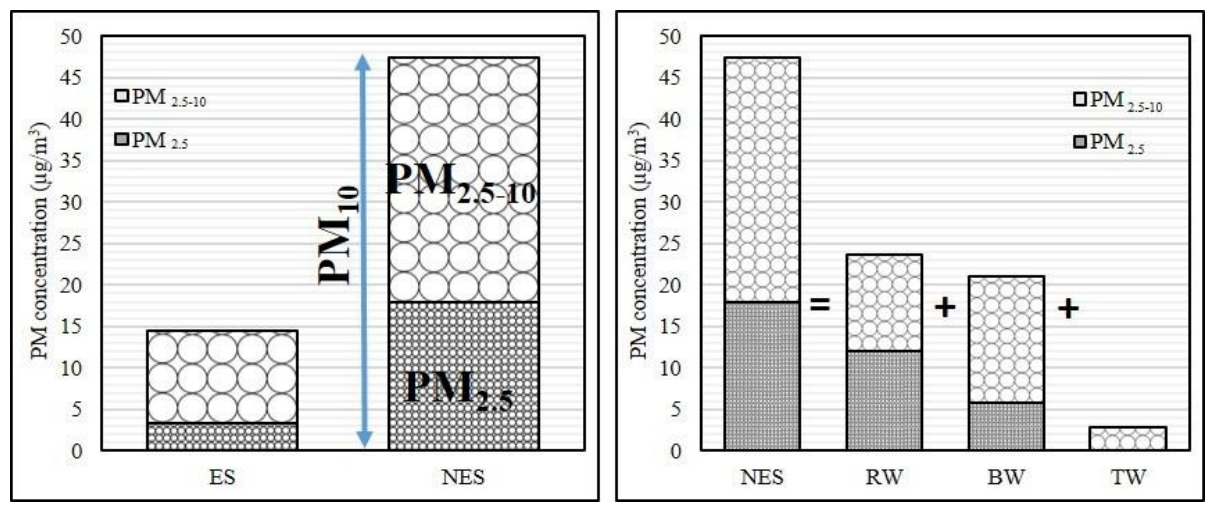

Figure 1. $\mathrm{PM}_{2.5}$ and $\mathrm{PM}_{10}$ for ES and NES

The contact between tyre and road surface causes shear and heat in the tyre (Jan Kole et al., 2017), with generation of wear particles. The interaction of tyres and pavement alters both the chemical composition and characteristics of the particles generated compared to the original tyre tread due to heat and friction, as well as the incorporation of material from the road surface (Grigoratos \& Martini, 2014; Panko et al., 2013). The amount and size of the particles released depends on climate (temperature), composition and structure of the tyre, road surface, driving speed and style, and the nature of the contact (e.g., rolling versus slipping). Kole et al. (2017) studied the tear and wear process and they summarised the amount released into the environment in different countries. Generally, two different approaches are used to estimate the amount of wear and tear from tyres: the first one uses emission factors per vehicle-km multiplied by the total mileage, and the second one uses the number of tyres multiplied by the weight loss of these tyres during use. Data collected have been grouped into 4 categories and reported in Table 5.

Table 5. The amount of car tyres wear and tear for different States (Jan Kole et al., 2017)

\begin{tabular}{|c|c|c|c|c|c|c|}
\hline \multirow{2}{*}{ Nation } & \multicolumn{4}{|c|}{ Wear and Tear in $(\mathrm{mg} / \mathrm{Km})$} & \multirow{2}{*}{$\begin{array}{l}\text { Total Wear and } \\
\text { Tear emissions } \\
\text { (Tonnes/years) }\end{array}$} & \multirow{2}{*}{$\begin{array}{c}\text { Total emissions } \\
\text { per Capita/year } \\
(\mathrm{kg})\end{array}$} \\
\hline & Category 1 & Category 2 & Category 3 & Category 44 & & \\
\hline The Netherlands & $9-60$ & $85-132$ & $102-159$ & $267-850$ & 8834 & 0.52 \\
\hline Norway & I & $100-132$ & I & 712 & 7884 & 1.5 \\
\hline Sweden & l & 50 & I & 700 & 13238 & 1.3 \\
\hline Denmark & l & $100-132$ & 204 & 712 & 6721 & 1.2 \\
\hline Germany & $22.5-45$ & $80-90$ & 180 & $700-1200$ & 92594 & 1.1 \\
\hline $\begin{array}{l}\text { United } \\
\text { Kingdom }\end{array}$ & I & l & l & l & 63000 & 0.98 \\
\hline Italy & I & I & I & I & 50000 & 0.81 \\
\hline Japan & $1136(2)^{*}$ & $1780(4)^{*}$ & $2880(4) *$ & $\begin{array}{l}5484(10)- \\
5973(14)^{*}\end{array}$ & 239762 & 1.9 \\
\hline China & 7 & 132 & 204 & 1068 & 756240 & 0.55 \\
\hline India & 7 & 132 & 204 & 1068 & 292674 & 0.23 \\
\hline Australia & I & I & I & I & 20000 & 0.87 \\
\hline USA & 7 & 132 & 204 & 1068 & 1524740 & 4.7 \\
\hline Brasil & 7 & 132 & 204 & 1068 & 294011 & 1.4 \\
\hline
\end{tabular}

Note: Category 1 - Moped, Motorcycle, and Motorised 2 - and 3 - wheelers; Category 2 - passenger car, light vehicle; Category 3 - van, special vehicle light, commercial car, lorry<7.5 t, light vehicle, and normal vehicle; Category 4 - articulated-lorry, lorry, truck, bus, special vehicle heavy, heavy transport, lorry $>7.5 \mathrm{t}$, trailer, and heavy lorry; *data refer to wear and tear are reported in $\mathrm{cm}^{3} /$ tyre. 
It is possible to observe as the amount of tyre wear and tear ranges from $9 \mathrm{mg} / \mathrm{km}$, for two-wheel vehicles like motorcycles, to $1200 \mathrm{mg} / \mathrm{km}$ for the heaviest vehicles (i.e., lorries). Moreover, the estimated per capita emission ranges from 0.23 to $4.7 \mathrm{~kg} /$ year, with a global average of $0.81 \mathrm{~kg} /$ year. In particular, India has the lowest wear and tear estimate, i.e., $0.23 \mathrm{~kg} /$ capita/year, while the USA has the highest, i.e., $4.7 \mathrm{~kg} / \mathrm{capita} / \mathrm{year}$. This difference can be explained by the fact that the USA has 0.82 cars per capita, while in India there are 0.13 cars per capita. The wear factor (defined as the total amount of material lost per kilometer) depends on several parameters such as: a) tyre characteristics; b) vehicle characteristics; c) road surface characteristics; d) vehicle operation. Many studies have been carried out to determine the amount of Particulate Matter (PM) emitted by non-exhaust source (e.g., tyres, brakes, and resuspension). Table 6 shows the $\mathrm{PM}_{10}$ and $\mathrm{PM}_{2.5}$ emissions caused by tyre wear process.

Table 6. $\mathrm{PM}_{10}$ and $\mathrm{PM}_{2.5}$ emission factor and concentration related to tyre wear

\begin{tabular}{|c|c|c|c|c|c|}
\hline \multirow{2}{*}{ References } & \multicolumn{2}{|c|}{$\begin{array}{l}\text { PM concentration } \\
\left(\mu \mathrm{g} / \mathrm{m}^{3}\right)\end{array}$} & \multirow{2}{*}{ References } & \multicolumn{2}{|c|}{$\begin{array}{l}\text { PM emission factor } \\
(\mathrm{mg} / \mathrm{vkm})\end{array}$} \\
\hline & $\mathrm{PM}_{10}$ & $\mathrm{PM}_{2.5}$ & & $\mathrm{PM}_{10}$ & $\mathrm{PM}_{2.5}$ \\
\hline (Sjödin et al., 2010) & $0.017-0.799$ & I & (Sjödin et al., 2010) & $0.002-0.044$ & l \\
\hline (Panko et al., 2019) & $0.04-2.24$ & $0.002-15$ & (Simons, 2013) & 0.004 & 0.003 \\
\hline (Panko et al., 2013) & $0.08-0.67$ & I & (ten Broeke et al., 2008) & $1.2-30$ & $0.25-6$ \\
\hline (Kwak et al., 2013) & $20.1-62.5$ & $17.2-52.6$ & $\begin{array}{c}\text { (EPA Environmental Protection } \\
\text { Agency, 2014) }\end{array}$ & $0.44-3.23$ & $3.04-21.69$ \\
\hline $\begin{array}{c}\text { (Gustafsson \& Eriksson, } \\
\text { 2015) }\end{array}$ & $0.004-0.011$ & $0.0036-0.012$ & (EMP/EEA, 2016) & $6.4-59$ & $3.4-16$ \\
\hline (Kupiainen et al., 2005) & 750 & 80 & (Timmers \& Achten, 2016) & $6.1-7.2$ & $2.9-3.7$ \\
\hline
\end{tabular}

Note: $\mathrm{mg} / \mathrm{vkm}=\mathrm{mg} \cdot \mathrm{Km}^{-1} \cdot$ vehicle $^{-1}$.

Brake linings consist of five different materials (Grigoratos \& Martini, 2014, 2015): 20-40\% (by mass) of binders (e.g., modified phenol-formaldehyde resins), 6-35\% of fibres (metallic, mineral, ceramic or organic), 15-70\% of fillers (e.g. inorganic compounds as barite $\left(\mathrm{BaSO}_{4}\right)$ or calcite $\left(\mathrm{CaCO}_{3}\right)$, silicates, and metal powders, 5-29\% of frictional additives or lubricants (e.g., graphite, metallic particles, carbon black, and antimony trisulphide) and $10 \%$ of abrasives (e.g. aluminium oxide, iron oxides, quartz and zircon). Brake lining materials have a chemical composition with a high content of metals such as $\mathrm{Fe}$ (up to $60 \%$ by weight), $\mathrm{Cu}, \mathrm{Zn}, \mathrm{K}$, Ti and $\mathrm{Pb}$ (up to $12 \%$ by weight) and other metals such as $\mathrm{Ba}, \mathrm{Mg}, \mathrm{Mn}, \mathrm{Ni}, \mathrm{Sn}, \mathrm{Cd}, \mathrm{Cr}$ at concentrations below 0.1\% (Penkała et al., 2018; Thorpe \& Harrison, 2008). 35-50\% of the brake wear debris becomes airborne particulate matter (PM) while the remaining particles are deposited on road surfaces or are attracted to other parts of the vehicle (Grigoratos et al., 2018; Hagino et al., 2016). The chemical and physical composition of the brake wear particles is affected by vehicle speed, driving behaviour, vehicle maintenance, ambient conditions and brake characteristics (Kwak et al., 2013). On-road measurements and laboratory measurements (e.g., brake dynamometer test) can be used to characterize emissions from brake wear. Based on a literary survey, Grigoratos and Martini (Grigoratos \& Martini, 2015) reported the following emission factors (EFs) for brake wear: 1) 2-8.8 mg km${ }^{-1} \mathrm{veh}^{-1}$ for $\mathrm{PM}_{10}$. 2) 0-15 mg km${ }^{-1} \mathrm{veh}^{-1}$ for $\mathrm{PM}_{2.5}$. 3) $1.2-3.1 \mathrm{mg} \mathrm{km}^{-1} \mathrm{veh}^{-1}$ for $\mathrm{PM}_{0.1}$, where mg stands for milligrams. Road asphalt consists of a mixture of various elements (Gustafsson, 2018) 1) Mineral aggregates containing elements such as $\mathrm{Si}, \mathrm{Ca}, \mathrm{K}, \mathrm{Fe}$, and $\mathrm{Al}$. 2) Bitumen with many compounds such as aliphatic and aromatic hydrocarbons. 3) Modifiers such as glass fillers, coal fly ash, and rubber tyres. The wearing of road surfaces depends on properties of asphalt, type of vehicle, and road surface conditions (Denier van der Gon et al., 2013). This affects the life and cycle costs of pavement and tire (Praticò et al., 2010), pavement properties, and acoustic performance. (Praticò, 2001, 2014). Different tracers such as asphaltenes and maltenes, metals (including vanadium, $\mathrm{Ni}, \mathrm{Fe}, \mathrm{Mg}$ and $\mathrm{Ca}$ ) or polycyclic aromatic hydrocarbons (PAHs) can be used for road surface wear, but it is difficult to distinguish the specific contribution of road wear and road dust (Thorpe \& Harrison, 2008). Apart from increasing with speed (Kwak et al., 2013), the increase in road wear particles depends on the type of tyre. To this end, it has been estimated that $\mathrm{PM}_{10}$ is 100 times higher for studded tyres than for standard tyres (Sjödin et al., 2010).

\section{Measures for PM mitigation}

Figure 2 and Table 7 show the main existing mitigation measures. 


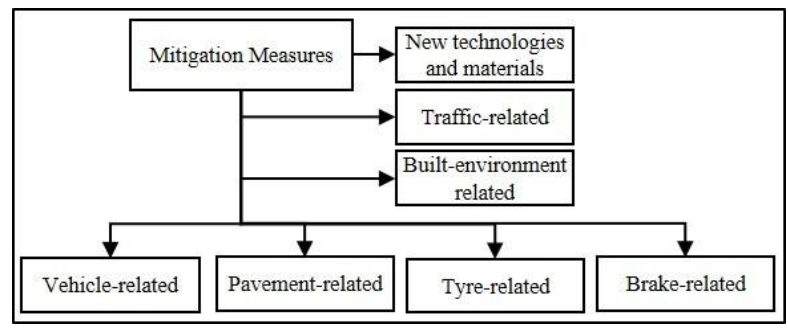

Figure 2. Mitigation measures

Table 7. Mitigation measures

\begin{tabular}{|c|c|}
\hline Source & Mitigation Measures \\
\hline \multirow[b]{2}{*}{ Pavement } & $\begin{array}{l}\text { Improvement of materials and maintenance of road surfaces. Mineralogical nature of aggregates and bitumen. } \\
\text { Type of pavement (e.g., porous asphalt concretes). Improving wear properties of materials. } \mathrm{TiO}_{2} \text {-like treatments. }\end{array}$ \\
\hline & $\begin{array}{l}\text { Road cleaning/Road maintenance. Flushing and washing. Vacuum sweeping (Monks et al., 2013). Binding dust to } \\
\text { road surface (dust binding, moistening) (Amato et al., 2014a, 2014b). Removing/immobilizing dust from road surface } \\
\text { ( Amato et al., 2014a, 2014b). Removing resuspended PM using dust suppressants (Monks et al., 2013). Storage and } \\
\text { handling of dusty materials (AIRUSE Project, 2016). }\end{array}$ \\
\hline Vehicle & $\begin{array}{l}\text { Reducing emission at the vehicle level (Gwilliam et al., 2004). Inspection and maintenance. Fuel quality; Alternative } \\
\text { fuels. Vehicle technology. Making technical instruments effective (successful introduction of new vehicles, fuels, and } \\
\text { emission control technologies). Retrofit (Yan et al., 2014) (e.g., Diesel particle filters (DPF) and diesel oxidation } \\
\text { catalysts (DOC) are two examples of retrofit technologies).Scrappage (Yan et al., 2014) (refers to the replacement of } \\
\text { old or high-emitting vehicles with newer ones that emit less pollution, before their owners would otherwise retire } \\
\text { them from use). }\end{array}$ \\
\hline \multirow[t]{2}{*}{ Brake } & $\begin{array}{l}\text { Reducing the formation of brake-source particles. Improving/optimising brake-pad friction material (e.g., Non- } \\
\text { Asbestos Organic (NAO) pad material (Perricone et al., 2018)).Using carbon ceramic disc to replace cast iron disc } \\
\text { (Wakeling et al., 2017). Regenerative brakes and brake-by-wire (Wakeling et al., 2017).Thermal disc treatment } \\
\text { (Perricone et al., 2018). }\end{array}$ \\
\hline & $\begin{array}{l}\text { Trapping particles. Using a capture technique. Vacuum cleaner type device (Chłopek et al., 2013). Brake Pad Waste } \\
\text { Collection System (BPWCS) (Fieldhouse \& Gelb, 2016). }\end{array}$ \\
\hline \multirow{2}{*}{ Tyre } & $\begin{array}{l}\text { Improvement of the composition and structure of the tyres (Verschoor et al., 2016). Wear-resistant tyres through } \\
\text { changed composition and construction methods (Tyres with silica used as filler are, for example, less susceptible to } \\
\text { wear than tyres with black carbon). Production of more resistant tyres to degradation (aging) from UV, moisture and } \\
\text { oxygen. }\end{array}$ \\
\hline & $\begin{array}{l}\text { Potential measures against emissions and dispersion of tyre abrasion (Verschoor \& de Valk, 2018). Legal } \\
\text { threshold value for tyre abrasion. Tyre label with tyre abrasion indicator. Prohibiting the use of winter tyres in } \\
\text { summer. Tyre Pressure Monitoring System in cars. Including wheel alignment in periodic vehicle inspections. } \\
\text { Kilometre price (Introduction of a kilometre tax). }\end{array}$ \\
\hline \multirow{3}{*}{ Traffic } & $\begin{array}{l}\text { Transport system improvement (Gwilliam et al., 2004). Modal-based strategies/Influencing modal choice. } \\
\text { Improving public transportation. Cycling and pedestrian lanes. Car-sharing. Electric, Hybrids and Gas Vehicles. }\end{array}$ \\
\hline & $\begin{array}{l}\text { Traffic management. Traffic management. Lowering number of cars in the urban areas. Lowering traffic speed. Low } \\
\text { emission zones (LEZ). Urban road tolls (Guevara, 2016). Key Access Regulation Schemes (Key-ARS) (Guevara, } \\
\text { 2016). }\end{array}$ \\
\hline & Fiscal policies. Polluting vehicle and fuel taxation. \\
\hline $\begin{array}{l}\text { Built- } \\
\text { environment }\end{array}$ & Offices, Farms, industries, and plants. \\
\hline Other & $\begin{array}{l}\text { SUNSPACE (SUstaiNable materials Synthesized from by-Products and Alginates for Clean air and better } \\
\text { Environment) (Zanoletti et al., 2018). Pollution Absorptive Billboard (Lima, Perù). Smog Free Tower in Beijing, } \\
\text { China (ionisation technology) (Khodadad \& Sanei, 2017). Air cleaning buildings (using TiO2). }\end{array}$ \\
\hline
\end{tabular}

\section{Conclusions}

Traffic-related sources account for $8-38 \%$ of $\mathrm{PM}_{10}$. On average, for exhaust sources (ES), $\mathrm{PM}_{10}$ accounts for about $10 \mu \mathrm{g} / \mathrm{m}^{3}$ and $\mathrm{PM}_{2.5}$ accounts for about $11 \mu \mathrm{g} / \mathrm{m}^{3}$. In addition, for non-exhaust sources (NES), $\mathrm{PM}_{10}$ accounts for about $12 \mu \mathrm{g} / \mathrm{m}^{3}$, and $\mathrm{PM}_{2.5}$ accounts for about $19 \mu \mathrm{g} / \mathrm{m}^{3}$. Furthermore, ES are often lower than NES but the opposite may happen. Even if more studies and measurements are needed, road wear usually outranks brake wear and tyre wear, with PM concentrations up to $13 \mu \mathrm{g} / \mathrm{m}^{3}$ and $42.8 \mu \mathrm{g} / \mathrm{m}^{3}$ for $\mathrm{PM}_{2.5}$ and $\mathrm{PM}_{10}$, respectively. Many mitigation measures can be adopted to reduce PM emissions and they can refer to vehicles, pavements, and other emission sources. A 
holistic approach to the design of pavements is required, by considering not only NES but also other properties (e.g., skid resistance and drainability). This study interacts with the project LIFE18 ENV/IT/000201 (LIFE E-VIA), where tyre-pavement interaction for non-exhaust sources emerges as a key factor.

\section{Funding}

This work was supported by the <European Commission> under Grant [LIFE E-VIA 18 ENV/IT/000201].

\section{Disclosure statement}

Authors declare that they have not any competing financial, professional, or personal interests from other parties.

\section{References}

AIRUSE Project. (2016). LIFE11/ENV/ES/584 - Testing and development of air quality mitigation measures in Southern Europe. Air quality mitigation measures in urban areas from Southern Europe. https://ec.europa.eu/environment/life/project/Projects/index.cfm?fuseaction=search.dspPage\&n_proj_id=4253\&docType=p df

Alanen, J., Simonen, P., Saarikoski, S., Timonen, H., Kangasniemi, O., \& Saukko, E. (2017). Comparison of primary and secondary particle formation from natural gas engine exhaust and of their volatility characteristics. Atmospheric Chemistry and Physics, 8739-8755. https://doi.org/10.5194/acp-2017-44

Amato, F., Alastuey, A., De La Rosa, J., Sánchez De La Campa, A. M., Pandolfi, M., Lozano, A., Contreras González, J., \& Querol, X. (2014a). Trends of road dust emissions contributions on ambient air particulate levels at rural, urban and industrial sites in southern Spain. Atmospheric Chemistry and Physics, 14(7), 3533-3544. https://doi.org/10.5194/acp-14-3533-2014

Amato, F., Cassee, F. R., Denier van der Gon, H. A. C., Gehrig, R., Gustafsson, M., Hafner, W., Harrison, R. M., Jozwicka, M., Kelly, F. J., Moreno, T., Prevot, A. S. H., Schaap, M., Sunyer, J., \& Querol, X. (2014b). Urban air quality: The challenge of traffic non-exhaust emissions. Journal of Hazardous Materials, 275, 31-36. https://doi.org/10.1016/j.jhazmat.2014.04.053

Chłopek, Z., Jakubowski, A., \& Kieracińska, A. (2013). Examination of a laboratory system to reduce dust emission from braking systems of automotive vehicle. The Archives of Automotive Engineering/ Archiwum Motoryzacji, 53(3), 5-17. https://doi.org/10.5604/1234754X.1066698

Denby, B. R., Sundvor, I., Johansson, C., Pirjola, L., Ketzel, M., Norman, M., Kupiainen, K., Gustafsson, M., Blomqvist, G., \& Omstedt, G. (2013). A coupled road dust and surface moisture model to predict non-exhaust road traffic induced particle emissions (NORTRIP). Part 1: Road dust loading and suspension modelling. Atmospheric Environment, 77, $283-300$. https://doi.org/10.1016/j.atmosenv.2013.04.069

Denier van der Gon, H. A. C., Gerlofs-Nijland, M. E., Gehrig, R., Gustafsson, M., Janssen, N., Harrison, R. M., Hulskotte, J., Johansson, C., Jozwicka, M., Keuken, M., Krijgsheld, K., Ntziachristos, L., Riediker, M., \& Cassee, F. R. (2013). The policy relevance of wear emissions from road transport, now and in the future - an international workshop report and consensus statement. Journal of the Air and Waste Management Association, 63(2), 136-149. https://doi.org/10.1080/10962247.2012.741055

Buchholz, R. A. (2014) National Ambient Air Quality Standards (NAAQS). In R. W. Kolb (Ed.), The SAGE encyclopedia of business ethics and society. https://doi.org/10.4135/9781483381503.n817

EPA Environmental Protection Agency. (2014). Brake and tire wear emissions from on road vehicles in MOVES2014.

European Parliament. (2008). Directive 2008/50/EC of the European Parliament and of the Council of 21 May 2008 on ambient air quality and cleaner air for Europe.

Fieldhouse, J. D., \& Gelb, J. (2016). New developments of an on-vehicle brake pad waste collection system. SAE International Journal of Passenger Cars - Mechanical Systems, 9(3), 1245-1254. https://doi.org/10.4271/2016-01-1949

Grigoratos, T., Gustafsson, M., Eriksson, O., \& Martini, G. (2018). Experimental investigation of tread wear and particle emission from tyres with different treadwear marking. Atmospheric Environment, 182, $200-212$. https://doi.org/10.1016/j.atmosenv.2018.03.049

Grigoratos, T., \& Martini, G. (2014). Non-exhaust traffic related emissions. Brake and tyre wear PM. Literature review. https://doi.org/10.2790/21481

Grigoratos, T., \& Martini, G. (2015). Brake wear particle emissions: A review. Environmental Science and Pollution Research, 22(4), 2491-2504. https://doi.org/10.1007/s11356-014-3696-8

Guevara, M. (2016). Emissions of primary particulate matter. In Airborne particulate matter: Sources, atmospheric processes and health. https://doi.org/10.1039/9781782626589-00001

Gustafsson, M. (2018). Review of road wear emissions. In Non-exhaust emissions (Chapter 8, pp. 161-181). Elsevier Inc. https://doi.org/10.1016/B978-0-12-811770-5.00008-X

Gustafsson, M., \& Eriksson, O. (2015). Emission of inhalable particles from studded tyre wear of road pavements. A comparative study (VTI rapport 867A).

Gwilliam, K., Kojima, M., \& Johnson, T. (2004). Reducing air pollution from urban transport (Main report). Washington, DC: World Bank. https://esmap.org/node/1145 
Hagino, H., Oyama, M., \& Sasaki, S. (2016). Laboratory testing of airborne brake wear particle emissions using a dynamometer system under urban city driving cycles. Atmospheric Environment, 131, 269-278. https://doi.org/10.1016/j.atmosenv.2016.02.014

Hedberg, E., Johansson, C., Johansson, L., Swietlicki, E., \& Brorström-Lundén, E. (2006). Is levoglucosan a suitable quantitative tracer for wood burning? Comparison with receptor modeling on trace elements in Lycksele, Sweden. Journal of the Air and Waste Management Association, 56(12), 1669-1678. https://doi.org/10.1080/10473289.2006.10464572

Heinrich, J., \& Slama, R. (2007). Fine particles, a major threat to children. International Journal of Hygiene and Environmental Health, 210(5), 617-622. https://doi.org/10.1016/j.ijheh.2007.07.012

Jan Kole, P., Löhr, A. J., Van Belleghem, F. G. A. J., \& Ragas, A. M. J. (2017). Wear and tear of tyres: A stealthy source of microplastics in the environment. International Journal of Environmental Research and Public Health, 14(10), 1265. https://doi.org/10.3390/ijerph14101265

Karagulian, F., Belis, C. A., Dora, C. F. C., Prüss-Ustün, A. M., Bonjour, S., Adair-Rohani, H., \& Amann, M. (2015). Contributions to cities' ambient particulate matter (PM): A systematic review of local source contributions at global level. Atmospheric Environment, 120, 475-483. https://doi.org/10.1016/j.atmosenv.2015.08.087

Khodadad, M., \& Sanei, M. (2017). Necessity of collaboration between technology and architectural design in order to develop the urban space quality. World Journal of Engineering and Technology, 5(4), 574-584. https://doi.org/10.4236/wjet.2017.54049

Kim, G., \& Lee, S. (2018). Characterization of Natural and Affected Environments Characteristics of tire wear particles generated by a tire simulator under various driving conditions. Environmental Science \& Technology, 52(21), 12153-12161. https://doi.org/10.1021/acs.est.8b03459

Kupiainen, K. J., Tervahattu, H., Räisänen, M., Mäkelä, T., Aurela, M., \& Hillamo, R. (2005). Size and composition of airborne particles from pavement wear, tires, and traction sanding. Environmental Science \& Technology, 39(3), 699-706. https://doi.org/10.1021/es035419e

Kwak, J. H., Kim, H., Lee, J., \& Lee, S. (2013). Characterization of non-exhaust coarse and fine particles from on-road driving and laboratory measurements. Science of the Total Environment, 458-460, 273-282. https://doi.org/10.1016/j.scitotenv.2013.04.040

Monks, P., Allan, J., Carruthers, D., Carslaw, D., Fuller, G., OBE, R. H., Heal, M., Lewis, A., Nemitz, E., Williams, M., \& Reeves, C. (2013). Non-exhaust emissions from road traffic. Air quality expert group.

https://uk-air.defra.gov.uk/assets/documents/reports/cat09/1907101151_20190709_Non_Exhaust_Emissions_typeset_Final.pdf

EMEP/EEA. (2016). EMEP/EEA air pollutant emission inventory guidebook 2016. European Environment Agency. https://doi.org/10.2800/247535

Panko, J., Hitchcock, K., Fuller, G., \& Green, D. (2019). Evaluation of tire wear contribution to PM2.5 in urban environments. Atmosphere, 10(2), 99. https://doi.org/10.3390/atmos10020099

Panko, J. M., Chu, J., Kreider, M. L., \& Unice, K. M. (2013). Measurement of airborne concentrations of tire and road wear particles in urban and rural areas of France, Japan, and the United States. Atmospheric Environment, 72, 192-199. https://doi.org/10.1016/j.atmosenv.2013.01.040

Penkała, M., Ogrodnik, P., \& Rogula-Kozłowska, W. (2018). Particulate matter from the road surface abrasion as a problem of nonexhaust emission control. Environments, 5(1), 9. https://doi.org/10.3390/environments5010009

Perricone, G., Matějka, V., Alemani, M., Valota, G., Bonfanti, A., Ciotti, A., Olofsson, U., Söderberg, A., Wahlström, J., Nosko, O., Straffelini, G., Gialanella, S., \& Ibrahim, M. (2018). A concept for reducing PM10 emissions for car brakes by $50 \%$. Wear, 396-397, 135-145. https://doi.org/10.1016/j.wear.2017.06.018

Praticò, F. G. (2001). Roads and loudness: A more comprehensive approach. Road Materials and Pavement Design, 2(4), 359-377. https://doi.org/10.1080/14680629.2001.9689908

Praticò, F. G. (2014). On the dependence of acoustic performance on pavement characteristics. Transportation Research Part D: Transport and Environment, 29, 79-87. https://doi.org/10.1016/j.trd.2014.04.004

Praticò, F. G., Ammendola, R., \& Moro, A. (2010). Factors affecting the environmental impact of pavement wear. Transportation Research Part D: Transport and Environment, 15(3), 127-133. https://doi.org/10.1016/j.trd.2009.12.002

Reddington, C. L., Carslaw, K. S., Spracklen, D. V, Frontoso, M. G., Collins, L., Merikanto, J., \& Minikin, A. (2011). Primary versus secondary contributions to particle number concentrations in the European boundary layer. Atmospheric Chemistry and Physics, 11, 12007-12036. https://doi.org/10.5194/acp-11-12007-2011

Schauer, J. J., Fraser, M. P., Cass, G. R., \& Simoneit, B. R. T. (2002). Source reconciliation of atmospheric gas-phase and particlephase pollutants during a severe photochemical smog episode. Environmental Science and Technology, 36(17), 3806-3814. https://doi.org/10.1021/es011458j

Simons, A. (2016). Road transport: New life cycle inventories for fossil-fuelled passenger cars and non-exhaust emissions in ecoinvent v3. International Journal of Life Cycle Assessment, 21, 1299-1313. https://doi.org/10.1007/s11367-013-0642-9

Sjödin, Å., Ferm, M., Björk, A., Rahmberg, M., Gudmundsson, A., Swietlicki, E., Johansson, C., Gustafsson, M., \& Blomqvist, G. (2010). Wear particles from road traffic - a field, laboratory and modelling study (Final report. June). 101.

Srimuruganandam, B., \& Shiva Nagendra, S. M. (2012a). Application of positive matrix factorization in characterization of PM 10 and PM 2.5 emission sources at urban roadside. Chemosphere, 88(1), 120-130. https://doi.org/10.1016/j.chemosphere.2012.02.083

Srimuruganandam, B., \& Shiva Nagendra, S. M. (2012b). Source characterization of PM 10 and PM 2.5 mass using a chemical mass balance model at urban roadside. Science of the Total Environment, 433, 8-19. https://doi.org/10.1016/j.scitotenv.2012.05.082 
ten Broeke, H., Hulskotte, J., \& Denier van der Gon, H. (2008, September). Road traffic tyre wear. Emission estimates for diffuse sources. Netherlands Emission Inventory Road.

Thorpe, A., \& Harrison, R. M. (2008). Sources and properties of non-exhaust particulate matter from road traffic: A review. Science of the Total Environment, 400(1-3), 270-282. https://doi.org/10.1016/j.scitotenv.2008.06.007

Timmers, V. R. J. H., \& Achten, P. A. J. (2016). Non-exhaust PM emissions from electric vehicles. Atmospheric Environment, 134, 10-17. https://doi.org/10.1016/j.atmosenv.2016.03.017

Verschoor, A., de Poorter, L., Dröge, R., Kuenen, J., \& de Valk, E. (2016). Emission of microplastics and potential mitigation measures. Abrasive cleaning agents, paints and tyre wear. National Institute for Public Health and teh Environment.

Verschoor, A. J., \& de Valk, E. (2018). Potential measures against microplastic emissions to water. National Institute for Public Health and teh Environment.

Wåhlin, P., Berkowicz, R., \& Palmgren, F. (2006). Characterisation of traffic-generated particulate matter in Copenhagen. Atmospheric Environment, 40(12), 2151-2159. https://doi.org/10.1016/j.atmosenv.2005.11.049

Wakeling, D., Murrells, T., Carslaw, D., Norris, J., \& Jones, L. (2017). The contribution of brake wear emissions to particulate matter in ambient air. Ricardo Energy \& Environment.

Weinbruch, S., Worringen, A., Ebert, M., Scheuvens, D., Kandler, K., Pfeffer, U., \& Bruckmann, P. (2014). A quantitative estimation of the exhaust, abrasion and resuspension components of particulate traffic emissions using electron microscopy. Atmospheric Environment, 99, 175-182. https://doi.org/10.1016/j.atmosenv.2014.09.075

WHO. (2006). WHO air quality guidelines for particulate matter, ozone, nitrogen dioxide and sulfur dioxide. World Health Organization. https://apps.who.int/iris/handle/10665/69477

Yan, F., Bond, T. C., \& Streets, D. G. (2014). Effectiveness of mitigation measures in reducing future primary particulate matter emissions from on-road vehicle exhaust. Environmental Science and Technology, 48(24), 14455-14463. https://doi.org/10.1021/es503197f

Zanoletti, A., Bilo, F., Borgese, L., Depero, L. E., Fahimi, A., Ponti, J., Valsesia, A., Spina, R. La, Montini, T., \& Bontempi, E. (2018). SUNSPACE, a porous material to reduce air Particulate Matter (PM). Frontiers in Chemistry, 6, 534. https://doi.org/10.3389/fchem.2018.00534 